\title{
IT'S A HARD KNOCK LIFE: A CRITIQUE OF THE LEGISLATIVE RESPONSE TO THE ORPHAN WORKS PROBLEM IN THE UK
}

\author{
Kyrsten Elena Baker*
}

\begin{abstract}
This article serves to identify the flaws in the three-pronged solution to the orphan works problem implemented in the UK. It concurrently questions the compatibility of the UK's approach with the objectives sought to be achieved by the legislation; namely to ensure legal certainty with respect to the use of orphan works, to facilitate cross-border access to orphan works, to facilitate mass digitisation projects and to ensure that authors' moral rights remain respected and protected. In addressing these issues, the article seeks to highlight aspects of the UK solution which could be amended in order to ensure that copyright law remains relevant and workable in the digital age, whilst maintaining a fair balance between protecting the interests of right holders and the public.
\end{abstract}

\section{A. INTRODUCTION}

Orphan works, defined as 'works ... protected by copyright ... for which no right holder has been identified, or, if identified, has not been located', represent a significant barrier to the establishment of comprehensive digital libraries and databases. ${ }^{1}$ Mass digitisation projects such as the Google Books Library and Europeana (a pan-European digital archive intended to facilitate the sharing of European cultural heritage) have been drastically hindered by the fact that copyright clearance could not be obtained for works whose authors could not be located. Even where such clearance could, theoretically, be secured through lengthy and costly search procedures, the transaction cost of such procedures often far exceeds the cost of digitising the material, resulting in market inefficiency. ${ }^{2}$

Organisational reluctance to initiate potentially fruitless and costly searches or, alternatively, to use works without authorisation and assume the risk of liability for copyright infringement, has resulted in 'many works 1 [ying] unused that could create great value'. ${ }^{3}$ Indeed, the value that these works could create is not limited to financial value. They offer

\footnotetext{
* Kyrsten Baker, LLB (Trinity College Dublin), LLM (University College London). The author would like to thank her friends, family, and independent research essay supervisor, Dr Ilanah Simon Fhima, for their support.

${ }^{1}$ Eleonora Rosati, 'The Orphan Works Directive, or Throwing a Stone and Hiding the Hand' (2013) 8(4) JIPLP 303, 303.

2 Anna Vuopala, 'Assessment of the Orphan Works Issue and Costs for Rights Clearance' (May 2010) <http://www.ace-film.eu/wp-content/uploads/2010/09/Copyright_anna_report-1.pdf> accessed 25 August 2015, 6.

${ }^{3}$ Andrew Gowers, 'Gowers Review of Intellectual Property’ (December 2006)

<https://www.gov.uk/government/uploads/system/uploads/attachment_data/file/228849/0118404830.pdf> accessed 25 August 2015, 70.
} 


\section{It's a Hard Knock Life: A Critique of the Legislative Response to the Orphan Works Problem in the $U K$}

invaluable insights into national culture, considered by the European Commission to be of paramount importance in achieving the European Union's 'strategic objectives of prosperity, solidarity and security'. ${ }^{4}$ Public access to a broad range of sources can also enable the exercise of freedom of speech by enhancing participation in the political discourse necessary to uphold democratic societies. ${ }^{5}$

In light of the difficulties created by orphan works, the European Commission and UK legislature are to be commended for recognising, through the implementation of the Orphan Works Directive 2012 (hereinafter OWD) and the orphan works provisions in the Enterprise and Regulatory Reform Act 2013 (hereinafter ERRA), that a legislative solution is required to prevent the disappearance of orphan works into a '20th century digital black hole'. 6 Commendable, too, are the underlying objectives of these legislative instruments; to ensure legal certainty with respect to the use of orphan works, ${ }^{7}$ to facilitate cross-border access to orphan works, to facilitate mass digitisation projects such as the Google Books Library Project, ${ }^{8}$ and to ensure that authors' moral rights remain respected and protected in the process. ${ }^{9}$

The purpose of this paper is not to propose a novel solution to the orphan works issue. Rather, it is to assess the adequacy of the solution which has been implemented in the UK. It seeks to determine whether the solution meets the aforementioned objectives and complies with relevant national and international legal requirements.

\footnotetext{
${ }^{4}$ Nadine Klass and Hajo Rupp, 'Europeana, Arrow and Orphan Works: Bringing Europe's Cultural Heritage Online' in Irini Stamadouti and Paul Torremans (eds), EU Copyright Law: A Commentary (Edward Elgar 2014) 948.

${ }^{5}$ Peter Menell, 'Knowledge Accessibility and Preservation Policy for the Digital Age' (2007) 44 Houston L Rev $1013,1042$.

${ }^{6}$ Council Directive 2012/28/EC on certain permitted uses of orphan works [2012] OJ L 299/5; James Boyle, 'A Copyright Black Hole Swallows our Culture' Financial Times (London, 6 September 2009) $<$ http://www.ft.com/intl/cms/s/0/6811a9d4-9b0f-11de-a3a1-00144feabdc0.html\#axzz3jmmKFT00> accessed 25 August 2015.

${ }^{7}$ OWD, Recital 9.

${ }^{8}$ European Commission, 'Impact Assessment on the Cross-Border Online Access to Orphan Works' COM (2011) 289 final <http://ec.europa.eu/internal_market/copyright/docs/orphan-works/impact-assessment_en.pdf> accessed 27 August 2015, 14; OWD, Recital 5; European Commission, 'Memorandum of Understanding on Key Principles on the Digitisation and Making Available of Out-of-Commerce Works' (Brussels, 2011) $<$ http://ec.europa.eu/internal_market/copyright/docs/copyright-infso/20110920-mou_en.pdf> accessed 25 August 2015; Eleonora Rosati, 'Copyright Issues Facing Early Stages of Digitization Projects' (Mobile Collections Project, December 2013)

$\langle$ http://www.digitalhumanities.cam.ac.uk/Copyrightissuesfacingearlystagesofdigitizationprojects.pdf $>$ accessed 27 August 2015, 11.

9 Intellectual Property Office, 'Orphan Works in the UK and Overseas' (July 2013) <https://www.gov.uk/government/uploads/system/uploads/attachment_data/file/312810/ipresearch-orphanoverseas-201307.pdf> accessed 25 August 2015, 12.
} 
Section B will explain why reverting to a system of copyright registration would be undesirable and will highlight the need for a novel solution to the orphan works problem. Section $\mathrm{C}$ will outline the current level of legislative intervention with regard to orphan works in the UK. Section D will question the degree of legal certainty it affords to potential users of orphan works. Section E will consider the ability of this legislation to facilitate cross-border access and mass digitisation efforts. Section F will assess its compliance with existing legal requirements. Section $\mathrm{G}$ will consider the respect and protection it affords to moral rights. The paper will conclude with a summary of its findings.

\section{B. THE NEED FOR A NOVEL SOLUTION}

Many attribute the emergence of the orphan works problem to the Berne Convention's prohibition on mandatory formalities as a condition for the 'enjoyment ... and exercise' of copyright. ${ }^{10}$ They call for the re-imposition of such formalities in the form of a mandatory registration requirement. ${ }^{11}$ This course of action, however, is unlikely to eliminate the problem. ${ }^{12}$ Whilst a registration requirement may ensure that only works intended to be exploited by their authors are protected by copyright, and would provide contact details for future potential users to seek licensing permissions, re-imposing such a formality would be impractical in 'the digital age'. ${ }^{13}$ The emergence of digital communication technologies has minimised publication and distribution costs, enabling many more individuals to become authors of copyrightable works. ${ }^{14}$ As Greenberg observes, requiring a blogger to register for copyright protection in respect of each of the multiple blog posts he might make on a daily basis would be prohibitively expensive. ${ }^{15}$ In many cases, that blogger will be unable to predict with accuracy which of his works are likely to be commercially successful and worth expending the effort required to gain copyright protection. ${ }^{16} \mathrm{~A}$ register would also need to be updated following any transfers of intellectual property rights, if it were to be of real assistance to prospective users of orphan works. ${ }^{17}$

\footnotetext{
${ }^{10}$ Stef van Gompel, 'Unlocking the Potential of Pre-Existing Content: How to Address the Issue of Orphan Works in Europe?' (2007) 38(6) IIC 669, 673; The Berne Convention for the Protection of Literary and Artistic Works (Berne Convention, as amended) Art 5(2).

${ }^{11}$ Christopher Sprigman, 'Reform(aliz)ing Copyright' (2004) 57 Stanford L Rev 485, 502.

12 Berne Convention, Art 5(2).

${ }^{13}$ Brad Greenberg, 'More Than Just a Formality: Instant Authorship and Copyright's Opt-Out Future in the Digital Age' (2012) 59 UCLALR 1028, 1033.

14 ibid 1035-1036.

15 ibid 1048.

16 ibid 1049.

${ }^{17}$ Bernard Lang, 'Orphan Works and the Google Book Search Settlement - an International Perspective' (201011) 55 NY Sch L Rev 111, 149.
} 
Such a registration requirement could actually discourage the creation of expressive works. Complying with a registration requirement would impose considerable costs upon serial creators, on top of the time and money initially expended in creating their works. It is likely to be more economically viable and require less time, money and effort for individuals to exploit existing unprotected works than to create and seek protection for their own. ${ }^{18}$ Thus, the problem of inaccessible works would merely be replaced with one of a dearth of creative works altogether. A novel solution, rather than a reversion in copyright policy, is required to resolve the orphan works problem.

\section{LEGISLATIVE EFFORTS TO ADDRESS THE ORPHAN WORKS PROBLEM}

The orphan works problem in the UK has been tackled using a three-pronged approach. The first prong consists of a narrowly circumscribed orphan works exception to the exclusive rights of reproduction and making available. This was introduced at EU level by the OWD, and has been implemented in the UK by the Copyright and Rights in Performances (Certain Permitted Uses of Orphan Works) Regulations 2014 (hereinafter CPUO Regulations). ${ }^{19}$ The regulations permit certain 'relevant bod[ies]' to reproduce orphan works for particular purposes and make them available, insofar as the use is in pursuit of a public interest mission. ${ }^{20}$ The orphan status of a work must be established by way of a diligent search before it may be used under this exception. ${ }^{21}$ The regulations set out mandatory sources to be consulted in the course of each diligent search, and list further relevant sources to be consulted for different categories of work. $^{22}$ 'Fair compensation' will be payable to reappearing rightholders for the use of their work(s) under the exception. ${ }^{23}$ The regulations also explicitly recognise the principle of mutual recognition set out in the OWD. ${ }^{24}$ Under this principle, works in respect of which a qualifying diligent search has been conducted will be automatically recognised as orphans in every EU Member State. This obviates the need for duplication of diligent searches. ${ }^{25}$

\footnotetext{
${ }^{18}$ Greenberg (n 13) 1050.

${ }^{19}$ SI 2014/2861.

20 ibid, ss 1-2; ibid, s 6(b).

${ }^{21}$ ibid, s 5 .

22 ibid, s 5(3)(a)-(b); ibid, pt 2.

23 ibid, s 7(3).

24 ibid, s 4.

${ }^{25}$ Rosati (n 1) 308.
} 
The second prong consists of a system of individual licensing for the use of orphan works. It is delineated in section 77 of the ERRA. ${ }^{26}$ Section 77 delegates to the Secretary of State much of the responsibility for determining how this system will operate in practice. The provisions she has made are contained in the Copyright and Rights in Performances (Licensing of Orphan Works) Regulations 2014 (hereinafter LOW Regulations). ${ }^{27}$ Like the CPUO Regulations, they require that a diligent search be carried out to confirm the orphan status of works for which licences are requested. ${ }^{28}$ The licences may authorise any act restricted by copyright, but may not grant exclusive rights in the work or be granted to a person authorised to grant licences. ${ }^{29} \mathrm{~A}$ 'reasonable licence fee' must be paid by the user of the orphan work. ${ }^{30}$ This fee will be repaid to a rightholder who reappears within eight years of the date on which the orphan licence was granted in respect of his work. ${ }^{31}$

The third prong consists of a system of extended collective licensing. It is also delineated in section 77 of the ERRA. ${ }^{32}$ Again, the Secretary of State is delegated a great deal of responsibility for determining the mechanics of the system. The provisions she has made are contained in the Copyright and Rights in Performances (Extended Collective Licensing) Regulations 2014 (hereinafter ECL Regulations). ${ }^{33}$ Under these regulations, licensing bodies fulfilling certain requirements may be authorised to grant copyright licences in respect of works in which the copyright is not owned by the body or any of its members. ${ }^{34}$ Non-members are afforded an option to opt-out. ${ }^{35}$ A licence fee will also be payable by prospective users of orphan works. ${ }^{36}$ This fee, minus a 'reasonable administration' fee, will be distributed to the relevant identifiable and locatable rightholders within nine months. ${ }^{37}$ The extended collective licensing scheme was intended to operate in parallel to the orphan works scheme, rather than

\footnotetext{
${ }^{26}$ Section 77 of the ERRA inserts a new section 116A into the Copyright, Designs and Patents Act 1988 which deals with the individual licensing of orphan works.

${ }^{27}$ LOW Regulations, SI 2014/2863.

28 ibid, s 4(1).

${ }^{29}$ ibid, s 6(2)(b); ibid, s 6(2)(a); ibid, s 6(4).

30 ibid, s 10(1)(a).

31 ibid, s 13(1).

${ }^{32}$ Section 77 of the ERRA also inserts a new section 116B into the Copyright, Designs and Patents Act 1988 which deals with extended collective licensing.

${ }^{33}$ SI 2014/2588.

34 ibid, s 2(a)-(b).

35 ibid, s 16(1).

36 ibid, s 18(1).

37 ibid.
} 
as a means of tackling the problem. ${ }^{38}$ However, Mendis notes that the licensing of orphan works may also be covered by such extended collective licences. ${ }^{39}$

\section{THE PROMISE OF LEGAL CERTAINTY}

\section{The Copyright and Rights in Performances (Certain Permitted Uses of Orphan Works) Regulations 2014}

In implementing the OWD, the CPUO Regulations do not provide prospective users of orphan works with sufficiently clear information to be certain that their actions will fall within the scope of the orphan works exception. There are three main causes for this lack of clarity within the regulations.

First, a number of terms used within the regulations are either poorly defined or completely undefined. Though section 2(1) lists 'relevant bod[ies]' that are entitled to use orphan works under the exception, no explicit definition is provided as to the meaning of a 'publicly accessible' institution. Nor is a clear definition provided for the meaning of a 'public interest mission'; the phrase is merely accompanied by a non-exhaustive list of examples. ${ }^{40} \mathrm{It}$ is also unclear whether the public or private nature of an institution is a relevant factor to be considered. ${ }^{41}$

Questions also arise regarding the definition of 'relevant works'. ${ }^{42}$ The CPUO Regulations suggest that only certain types of work held in the collections of certain beneficiary institutions will constitute relevant works. Section 2(2)(a) indicates that 'a work in the form of a book, journal, newspaper, magazine or other writing' will only be deemed 'relevant' where it is contained in the collection of a 'publicly accessible library, educational establishment, museum, archive or film or audio heritage institution'. It is not clear whether the reference to 'other writings' is intended to refer only to classic forms of literary work akin to those enumerated, or also to more modern forms such as computer programmes and source codes. ${ }^{43}$ Section 2(2)(c) indicates that 'cinematographic works, audiovisual works and sound recordings' are the only forms of work contained in the archive of a public service broadcasting

\footnotetext{
38 Dinusha Mendis, 'Orphan Works' (COPYRIGHTUSER.ORG) <http://copyrightuser.org/topics/orphanworks/> accessed 26 August 2015.

${ }^{39}$ ibid.

${ }^{40}$ CPUO Regulations, s 6(b).

${ }^{41}$ Marie-Christine Janssens and Rán Tryggvadóttir, 'Facilitating Access to Orphan and Out of Commerce Works to Make Europe's Cultural Resources Available to the Broader Public' (2014) $<$ http://ssrn.com/abstract=2538097> accessed 26 August 2015, 9.

42 CPUO Regulations, s 2.

${ }^{43}$ Uma Suthersanen and Maria Mercedes Frabboni, 'The Orphan Works Directive' in Irini Stamadouti and Paul Torremans (eds) EU Copyright Law: A Commentary (Edward Elgar 2014) 653, 659.
} 
organisation which may be deemed 'relevant works'. It is unclear why a 'book, journal, newspaper, magazine or other writing' contained in the archive of a public service broadcasting organisation may not also achieve 'relevant work' status. It is also unclear whether institutions are confined only to one, or may fall under multiple 'relevant body' classifications. ${ }^{44}$ Arguably, a library may also be considered an educational establishment, a museum also an archive, and a broadcasting organisation also a film or audio heritage institution. No definition is provided for any of these terms.

The regulations also state that a rightholder may put an end to the orphan status of a work by providing evidence of his ownership. ${ }^{45}$ However, no clear indication is provided as to what standard of 'evidence' is required, or what form it should take. The method by which the 'fair compensation' to which a reappearing rightholder is entitled is to be calculated is also unclear. Furthermore, no definition is provided of the 'reasonable period' within which a rightholder is entitled to claim such compensation. ${ }^{46}$

Secondly, it is extremely difficult for prospective users of orphan works to know whether certain obligations imposed upon them by the regulations have been fulfilled. Though the regulations require that a diligent search be conducted to determine the orphan status of a work, and set out relevant sources to be consulted for each category of relevant work, they fail to specify whether consulting each of the specified sources will automatically guarantee operation of the exception. The regulations also require that consultation of these sources be conducted either in the Member State in which the work was first published or broadcast, or the Member State in which the organisation that first made the work available with the consent of the rightholders is established. ${ }^{47}$

Given that the information potential users have about orphan works and their owners is necessarily limited, it will not be easy to determine whether a work is protected by copyright and has been published or broadcast, let alone to determine in which Member State this may have occurred. Indeed, no independent body is appointed to verify the diligence of a search. ${ }^{48}$

\footnotetext{
${ }^{44}$ Robin Kerremans, 'A Critical View on the European Draft Directive for Orphan Works' (2012) 1 QMJIP 38, 53.

${ }^{45}$ CPUO Regulations, s 7(2).

46 ibid, s 7(3).

47 ibid, s 5(5); ibid, s 5(7).

${ }^{48}$ Intellectual Property Office, 'Government Response to the Technical Consultation on Orphan Works' (July 2012)

<https://www.gov.uk/government/uploads/system/uploads/attachment_data/file/315078/Orphan_Works_Govern ment_Response.pdf> accessed 26 August 2015, 5.
} 


\section{It's a Hard Knock Life: A Critique of the Legislative Response to the Orphan Works Problem in the $U K$}

Prospective users of orphan works are, therefore, required to 'self-assess' the adequacy of their diligent search efforts. ${ }^{49}$

Section 2(4) of the regulations states that use may only be made of orphan works under the exception 'as long as it is reasonable to assume that the rightholders would not oppose the use of the work'. It is likely to be almost impossible for a prospective user of orphan works to prove the reasonableness of his assumption that a rightholder, about whom he has no information, would not oppose the use he intends to make of the work. ${ }^{50}$

Thirdly, the regulations fail to provide guidance as to the correct course of action where foreseeable difficulties arise. One such foreseeable difficulty is a lack of response from institutions contacted in the course of a diligent search. The CPUO Regulations do not impose any statutory obligation on the institutions listed to respond to diligent search requests. ${ }^{51}$ Nor do they clarify how long the applicant is reasonably expected to wait for a response. Another foreseeable difficulty is the charging of excessive fees by institutions in return for provision of requested information about a particular work. ${ }^{52}$ Both difficulties constitute reasons for noncompliance with diligent search requirements that are outside the applicant's control. It would surely be unjust if these reasons for non-compliance served to invalidate an otherwise diligent search. Unfortunately, whether or not such reasons for non-compliance would invalidate a search is not addressed within the regulations.

The degree of ambiguity evident in the CPUO Regulations is particularly concerning, given that beneficiary institutions in pursuit of a 'public interest mission' are likely to have limited funds with which to secure sophisticated legal advice.

\section{The Copyright and Rights in Performances (Licensing of Orphan Works) Regulations 2014}

Regrettably, the system of individual licensing detailed in the LOW Regulations reflects a number of the same uncertainties which plague the CPUO Regulations. The LOW Regulations also fail to implement a statutory obligation on listed institutions to respond to diligent search requests, and to clarify how a reappearing rightholder is to 'satisfy the authorising body...of

\footnotetext{
${ }^{49}$ Ellen Franziska Schulze, 'Orphan Works and other Orphan Material under National, Regional and International Law: Analysis, Proposals and Solutions’ (2012) 34(5) EIPR 313, 317.

50 Janssens and Tryggvadóttir (n 41) 12.

51 Theo Savvides and Briony Pollard, 'Who's Your Daddy? Orphan Works and the New UK Licensing Scheme and Exception for Permitted Use' Intellectual Property Magazine (London, December 2014) <http://www.intellectualpropertymagazine.com/branding/whos-your-daddy-105011.htm> accessed 27 August 2015.

52 ibid.
} 
their ownership ... of relevant rights in the orphan work' ${ }^{53}$ Though they offer somewhat more guidance as to calculation of the payable licensing fee than the CPUO Regulations regarding 'fair compensation', this additional guidance is inadequate. It is not sufficiently clear to enable prospective users to predict the level of licensing fees that will be payable for particular uses of orphan works. Section 10(1)(a) indicates that, in calculating payable licence fees, regard should be had to the fees achieved under licences for similar uses of similar non-orphan works. However, it is not clear in what sense the works should be similar. If the orphan work happened to be Anne Frank's Diary, would 'similar' non-orphan works be other diaries written by adolescents during the Holocaust, or, more generally, any other literary works?

Three more areas of ambiguity within the LOW Regulations are particularly apparent. First, though section 6(4) specifies that a licence to use orphan works may not be granted to 'a person authorised to grant licences', it is unclear whether this extends just to the ComptrollerGeneral, or also to others working in the Intellectual Property Office. If 'person' were intended to cover legal as well as human persons, it is also conceivable that the restriction on granting orphan works licences could extend to the Intellectual Property Office itself, given that 'a legal person is any individual, firm or government agency with the right to enter into binding agreements. $^{54}$

Secondly, uncertainty stems from the conflicting conceptions of a 'relevant work' in sections 3(1) and 3(6). While section 3(1) defines a relevant work as 'a work protected by copyright or a performance in respect of which certain acts constitute restricted acts', section 3(6) refers to relevant work[s] 'in which it is not known whether copyright or the right to permit or prohibit the restricted act subsists'. ${ }^{55}$ The inconsistency between the two regulations leaves prospective users unclear as to whether copyright protection is a necessary prerequisite to obtaining an orphan licence. If it is, similar difficulties in confirming the existence of such copyright protection arise as under the CPUO Regulations.

Thirdly, the broad discretion afforded to the authorising body under section 6(5)(b) to refuse to grant licences 'on any....reasonable ground' is likely to cause uncertainty amongst prospective users as to whether they are likely to be granted an orphan works licence. Given

\footnotetext{
${ }^{53}$ LOW Regulations, s 12(1).

${ }^{54}$ Lewis Kornhauser and Bentley MacLeod, 'Contracts Between Legal Persons' (2010) National Bureau of Economic Research 1, 2.

55 Tom Rivers, 'A Fuss About Something?' (2015) 37(1) EIPR 4, 7.
} 


\section{It's a Hard Knock Life: A Critique of the Legislative Response to the Orphan Works Problem in the $U K$}

the prevalence of the organisational 'risk managed' mentality, such uncertainty may discourage prospective users of orphan works from assuming the cost of diligent searches. ${ }^{56}$

\section{The Copyright and Rights in Performances (Extended Collective Licensing) Regulations 2014}

Perhaps the greatest legal uncertainty facing prospective orphan work users is whether or not the ECL Regulations permit the grant of extended collective licences for the use of orphan works. Despite statements from the Intellectual Property Office suggesting that extended collective licensing is 'not intended to be the default solution for licensing works that are, or could be orphans', the ECL Regulations do not explicitly exempt orphan works from their remit. ${ }^{57}$ In order to obtain authorisation to grant extended collective licenses, relevant licensing bodies must demonstrate that they represent 'a significant number of rightholders relevant to the works and uses covered by the proposed scheme' ${ }^{58}$ However, no guidance is provided as to what is meant by 'significant'. If 'a significant number' is intended to refer to a majority of relevant rightholders, this majority representation could easily be obtained without involving orphan work rightholders. This supposes, not inconceivably, that rightholders in orphan works constitute the minority in any given category of work or use. Being non-locatable and in the minority, orphan work rightholders would fall into the class of 'non-member rightholder[s]' who have not opted out, on behalf of whom relevant licensing bodies are authorised to grant extended collective licences. Even if 'a significant number' simply intended to mean a number of rightholders that is not insignificant, relevant licensing bodies will still be able to show that they are sufficiently representative without involving orphan rightholders. This task would, in fact, be easier than if 'significant' was intended to refer to a majority.

In light of this analysis, it is unfortunate that the Intellectual Property Office has expressed the aforementioned doubts regarding the applicability of the extended collective licensing scheme to orphan works. These are likely to confuse prospective users of orphan works as to the licensing options available to them.

\footnotetext{
${ }^{56}$ Naomi Korn, 'In from the Cold: An Assessment of the Scope of 'Orphan Works' and its Impact on the Delivery of Services to the Public' (April 2009)

<http://www.webarchive.org.uk/wayback/archive/20140615221324/http:/www.jisc.ac.uk/media/documents/publ ications/infromthecoldv1.pdf> accessed 26 August 2015, 6.

${ }^{57}$ Intellectual Property Office, 'FACTSHEET - Orphan Works Licensing Scheme and Extended Collective Licensing' (June 2014)

<http://webarchive.nationalarchives.gov.uk/20140603093549/http://www.ipo.gov.uk/orphanworkslicensing.pdf $>$ accessed 26 August 2015.

${ }^{58}$ ECL Regulations, s 4(4)(b).
} 
Expressing such doubts is even more regrettable when one takes into consideration the fact that seeking an extended collective licence is a much more attractive option for prospective users of orphan works than that provided by either the CPUO or LOW Regulations. Though relevant licensing bodies are obliged under section 18(3) of the ECL Regulations to 'distribute the appropriate portion of the net licence fee to those non-member rightholders who have been identified and located', no guidance is provided as to the standard of search required to identify and locate such rightholders. Therefore, it is estimated that the expected standard of search would fall below the 'diligent search' standard required by the LOW Regulations. Whatever the required standard of search, responsibility for meeting it is transferred from the prospective user to the relevant licensing body. Thus, by obtaining an extended collective licence to use orphan works, users could avoid expending time, effort and money in conducting potentially fruitless diligent searches.

\section{E. FACILITATING CROSS-BORDER ACCESS AND MASS DIGITISATION}

\section{The Copyright and Rights in Performances (Certain Permitted Uses of Orphan Works) Regulations 2014}

Had the OWD lived up to its title as an instrument fit to 'remove market fragmentation and provide a legal framework that favours EU competitiveness', the transposing CPUO Regulations could have played a small part in harmonising the approach of all EU Member States with respect to orphan works. ${ }^{59}$ If this approach had been harmonised, cross-border operations involving the use of orphan works in the EU could have been made simpler and cheaper. Corporations operating across a number of EU countries could have significantly reduced the regulatory cost involved in complying with differing national licensing and diligent search requirements. Those involved in mass digitisation initiatives could have similarly benefitted. Regrettably, the OWD has failed to realise these potential benefits. In providing for an extremely limited exception available only to a restricted list of institutions, and in stating that it operates without prejudice to national systems of rights management, the OWD invites the establishment of additional, potentially conflicting, national regimes. In effect, it actively discourages any potentially harmonising effect. As Rosati submits, where Member States

\footnotetext{
${ }^{59}$ Janssens and Tryggvadóttir (n 41) 4.
} 


\section{It's a Hard Knock Life: A Critique of the Legislative Response to the Orphan Works Problem in the $U K$}

remain free to select their own regulatory approach to orphan works, there is 'no room for the creation of an EU level playing field'. ${ }^{60}$

This broad discretion afforded to Member States fails to address the existing difficulties faced by those involved in mass online digitisation projects. Given the territorial nature of intellectual property rights, the legality of making works available on the internet tends to be judged according to the laws of each country in which they are made available. ${ }^{61}$ Therefore, the greater the variations in approach to orphan rights management across different jurisdictions, the more costly and difficult it is to ensure that one's use of an orphan work online complies with every system.

The degree of uncertainty which surrounds the issue of the applicable law in cases of online copyright infringement serves only to make compliance more difficult. Though Article $5(2)$ of the Berne Convention states that 'the extent of [copyright] protection, as well as the means of redress afforded to the author to protect his rights, shall be governed exclusively by the laws of the country where protection is claimed', Wilson notes that the 'country where protection is claimed' has been afforded many differing interpretations. ${ }^{62}$ In internet cases, it has been taken to refer to the place where the effect of the infringement is felt, the place where the work has been accessed, and, more recently, the place in which the servers enabling access to the material are located. ${ }^{63}$ This uncertainty further highlights the need for a fully harmonised EU-wide (if not global) orphan works solution.

The OWD and transposing CPUO Regulations attempt to cloak the feebleness of this attempt at harmonisation behind the façade of mutual recognition of orphan work status. This principle is unlikely to have much of a mitigating effect in practice, however. Under EU law, Directives are mandatory only with regard to the result to be achieved, meaning that Member States are afforded a margin of appreciation in determining the form that the implementing measures will take. ${ }^{64}$ Therefore, the exception is likely to be implemented by Member States in varying forms. Some, like the UK, will choose to implement various forms of orphan work

\footnotetext{
${ }^{60}$ Eleonora Rosati, 'The Orphan Works Provisions of the ERR Act: Are They Compatible with UK and EU Laws?' (September 2013) <http://papers.ssrn.com/sol3/papers.cfm?abstract_id=2323393> accessed 25 August 2015,35 .

${ }^{61}$ Allard Ringnalda, 'Orphan Works, Mass Rights Clearance, and Online Libraries: The Flaws of the Draft Orphan Works Directive and Extended Collective Licensing as a Solution' (2011) 8 Medien und Recht International 3, 5. 62 Amanda Wilson, 'Jet-Setting Orphan Works: The Transnational Making Available of Works of Unknown Authorship, Anonymous Works, or Lost Authors' (2009) 23 Emory Int'1 L Rev 783, 818-819.

${ }^{63} \mathrm{ibid}$; Société des auteurs des arts visuels et de l'image fixe v SARL Google France, Tribunal de grande instance, Paris, 20 May 2008, 05/12117, 7-8.

${ }^{64}$ Norbert Reich, Understanding EU Law: Objectives, Principles and Methods of Community Law (Intersentia Publishers 2003) 21.
} 
licensing system in addition to the exception. Indeed, mutual recognition does not account for the fact that differences in national copyright law may mean that a work which is orphaned in one jurisdiction is not orphaned in another. ${ }^{65}$ For example, Dutch copyright law dictates that an employer owns all rights in works created by his employees in the course of their employment. ${ }^{66}$ Under German copyright law, however, the rights vest in the employeecreator. ${ }^{67}$ An inability to locate the employer following a diligent search would result in the work being deemed an orphan work under Dutch law, but would have no bearing on the status of the work under German law.

The fact that the orphan works exception applies only to certain institutions pursuing public interest missions operates as a further barrier to mass digitisation efforts. With commercial operations excluded from its scope, the exception is wholly unsuited to facilitating the use of orphan works in commercial mass digitisation initiatives such as the Google Books Library. Even non-commercial initiatives are likely to be significantly hindered by the fact that stand-alone photographs and images are excluded from the scope of the exception. Undoubtedly, images could add a great deal to a 'repository of cultural heritage' such as Europeana. ${ }^{68}$ Their exclusion appears particularly anomalous in light of the fact that photographs tend to bear less identifying information than other kinds of work, and therefore are significantly more susceptible to orphanage. ${ }^{69}$

In addition, fulfilling the requirement that a diligent search be conducted in respect of each orphan work intended to be used under the exception 'may be prohibitively costly' in the context of mass digitisation. ${ }^{70}$ The fact that section $5(8)$ requires consultation of sources of information 'in other countries', where there is evidence to suggest that relevant information on rightholders is to be found there, and is not limited to other European countries, increases the likelihood that carrying out multiple diligent searches will be prohibitively costly. ${ }^{71}$

\footnotetext{
${ }^{65}$ Wilson (n 62) 786.

${ }^{66}$ Mireille van Eechoud, Choice of Law in Copyright and Related Rights: Alternatives to the Lex Protectionis (Kluwer Law International, 2003) 19.

67 ibid.

${ }^{68}$ Europeana, 'Europeana Strategy 2015-2020' (Europeana: Think Culture) <http://strategy2020.europeana.eu/> accessed 26 August 2015.

${ }^{69}$ Katharina de la Durantaye, 'Finding a Home for Orphans: Google Book Search and Orphan Works Law in the United States and Europe’ (2011) 21 Fordham Intell Prop Media \& Ent LJ 229, 234.

${ }^{70}$ Maurzio Borghi and Stavroula Karapapa, Copyright and Mass Digitization (OUP 2013) 2.

${ }^{71}$ Janssens and Tryggvadóttir (n 41) 18.
} 


\section{The Copyright and Rights in Performances (Licensing of Orphan Works) Regulations 2014}

While the licensing scheme provided for by the LOW Regulations is available to both commercial and non-commercial users, the fact that it also requires a diligent search for each orphan work renders it similarly unsuited to facilitating the use of orphan works in mass digitisation initiatives.

In addition, the regulations facilitate cross-border access to orphan works only to a limited extent. Despite allowing for the grant of licences for the use of orphan works hailing from foreign jurisdictions, these licences are valid only in the UK. ${ }^{72}$ Thus, while cross-border access to orphan works is enhanced for initial users seeking to make use of the work, such access is not concurrently enhanced for consumers of mass digitised materials. Because the terms of such orphan works licences only permit use of the work within the UK, disseminating the work online would likely constitute a breach of the terms of the licence, even when existing ambiguities as to the correct 'place of infringement' are accounted for.

Though technological protection measures such as geo-blockers may be used to restrict access to orphan materials to solely UK-based users, the premise behind mass digitisation projects is that they facilitate the sharing of information on a large scale. It is highly improbable that the goal shared by both Europeana and the Google Books Library to 'democratize access to the world's collective knowledge' could be achieved through disseminating materials online in only one country. ${ }^{73}$ Furthermore, as Savvides and Pollard note, technological protection measures are costly and time-consuming to operate, and require regular updating to keep pace with technological advances. ${ }^{74}$ They also operate 'blind', in the sense that they are unable to discern whether a user is about to make a lawful or unlawful use of a work. ${ }^{75}$

Having to pay a licence fee prior to the use of individual orphan works also hinders the number of orphan works that may be used in mass digitisation projects. Licence fee payments eat away at the finite financial resources backing mass digitisation initiatives. Evidently, the more licence fees that must be paid, the fewer orphan works that may be used. There appears to be no good reason why this fee could not be paid upon reappearance of orphan works

\footnotetext{
${ }^{72}$ LOW Regulations, s 6(1)(a).

73 Josh Katz, 'Europeana Aims to Digitize Europe's Libraries' (Finding Dulcinea, 21 November 2008)

<http://www.findingdulcinea.com/news/business/2008/November/Europeana-Aims-to-Digitize-Europe-sLibraries.html> accessed 26 August 2015.

${ }^{74}$ Savvides and Pollard (n 51).

${ }^{75}$ Christophe Geiger, 'Copyright and Free Access to Information: For a Fair Balance of Interests in a Globalised World’ (2006) 28 EIPR 366, 369.
} 
rightholders, rather than upfront. Given that rightholders are unlikely to reappear in the majority of cases, prospective users could retain fees which would otherwise be used to fund arbitrary 'social, cultural and educational activities' and make greater use of orphan works. ${ }^{76}$

\section{The Copyright and Rights in Performances (Extended Collective Licensing) Regulations 2014}

In one sense, the licensing system envisaged by the ECL Regulations appears much better suited to facilitating the use of orphan works in mass digitisation projects than the previous two options. Unlike the CPUO and LOW Regulations, the ECL Regulations impose no obligation upon prospective users of presumed orphan works to conduct diligent searches. Thus, users seeking to digitise orphan work materials on a mass scale would not face the high transaction costs involved in individual rights clearance under the orphan work exception and individual licensing models.

However, like the individual orphan works licensing system under the LOW Regulations, extended collective licensing schemes require upfront payment of licence fees. They are also limited in their ability to facilitate cross-border access to orphan works. While both models appear to allow licensing in respect of works of foreign origin, both forms of licence are valid only within the territory in which they are granted.

Indeed, the legitimacy of allowing relevant licensing organisations to grant extended collective licences in respect of foreign works is questionable, at the very least. Though the Intellectual Property Office has stated that, under the ECL Regulations, 'foreign rights-holders will be in the same position as UK rights holders', this claim does not correspond with the stated representation requirements. ${ }^{77}$ As previously discussed, section 4(4)(b) requires relevant licensing bodies to have significant representation in the type of relevant works which are to be the subject of the proposed extended collective licensing scheme. Section 2 defines 'representation' as the extent to which the relevant licensing body currently acts on behalf of rightholders and holds rightholders' rights in respect of the works relevant to the proposed licensing scheme. If foreign rightholders' works are intended to be included in an extended collective licensing scheme, it is unlikely that a UK-based relevant licensing authority could act on behalf of, and hold the rights of a 'significant number' of works within the global, or even EU-wide sphere. This applies whether 'a significant number' is intended to mean a majority or merely a not-insignificant number. Again, the regulations provide no interpretative

\footnotetext{
76 ibid, s 13(2).

${ }^{77}$ Intellectual Property Office (n 57).
} 


\section{It's a Hard Knock Life: A Critique of the Legislative Response to the Orphan Works Problem in the $U K$}

guidance in this regard, though De la Durantaye supports the view of this author that no one relevant licensing authority could represent a significant number of rightholders from all European Member States. ${ }^{78}$

Regardless of the legitimacy of granting licences in respect of foreign works, users seeking to disseminate orphan materials online under extended collective licences without extra-territorial effect face the same risk of breaching licence terms as licensees under the LOW Regulations.

\section{F. COMPLIANCE WITH EXISTING LEGAL REQUIREMENTS}

As a signatory of the Berne Convention, the UK legislature is bound by the prohibition in Article 5(2) of the imposition of mandatory formalities as a condition for the normal exercise or enjoyment of rights (including copyright). Article 9(2) authorises contracting states to provide for exceptions and limitations to the right of reproduction, only to the extent that they comply with what has become known as 'the three-step test'. According to this test, exceptions or limitations must constitute 'special cases' and they must not 'conflict with the normal exploitation of the work' or 'unreasonably prejudice the legitimate interests of the author'. This test is re-stated in Article 5(5) of the Information Society Directive and Article 13 of the Agreement on Trade-Related Aspects of Intellectual Property Rights, to which the UK is also party. $^{79}$

Exceptions to copyright owners' exclusive rights are partially harmonised throughout Europe. ${ }^{80}$ Though the Information Society Directive enumerates an exhaustive list of exceptions and limitations, Member States are afforded a great deal of discretion as to how and which of these exceptions are implemented at national level. ${ }^{81}$ Only one exception, covering transient or incidental copying as part of a network transmission or legal use, is mandatory, and many of the remaining exceptions are so broadly worded that they have been deemed 'prototypes for national law-making, rather than precisely circumscribed exceptions'. ${ }^{2}$

\footnotetext{
${ }^{78}$ De la Durantaye (n 69) 264.

${ }^{79}$ Council Directive 2001/29/EC [2001] OJ L 167/10. To view the parties see: 'Other IP Treaties' (WIPO: World Intellectual Property Organisation)

<http://www.wipo.int/wipolex/en/other treaties/parties.jsp?treaty id=231\&group id=22> accessed 27 August 2015.

${ }^{80}$ Mark Owen, 'EU Copyright Reform: a Pirate Takes the Helm' TTLF Newsletter on Transatlantic Antitrust and IPR Developments (23 March 2015) < https://ttlfnews.wordpress.com/2015/03/23/eu-copyright-reform-a-piratetakes-the-helm/> accessed 26 August 2015.

${ }^{81}$ Kerremans (n 44) 40.

${ }^{82}$ P Bernt Hugenholtz and Martin Senftleben, 'Fair Use in Europe: In Search of Flexibilities' (2012) Amsterdam Law School Research Paper No 2012-39 <http://papers.ssrn.com/sol3/papers.cfm?abstract_id=1959554> accessed 26 August 2015, 14.
} 


\section{The Copyright and Rights in Performances (Certain Permitted Uses of Orphan Works) Regulations 2014}

Recital 32 of the Information Society Directive states that it "provides for an exhaustive enumeration of exceptions and limitations to the reproduction right and the right of communication to the public'. It is axiomatic, therefore, that introducing a new orphan works exception, which the OWD and CPUO Regulations purport to do, necessitates amendment of this Directive. ${ }^{83}$ However, provision for such an amendment does not appear to have been made. Indeed, the fact that Recital 20 of the OWD says 'Member States should provide for an exception or limitation in addition to those provided for in Article 5 of Directive 2001/29/EC [emphasis added]' could arguably be taken to mean that amendment of the existing list is not envisaged, and that the exception is intended to simply co-exist with this list.

This argument is supported by the fact that no explicit mention is made in the OWD or the CPUO Regulations of the need to amend the Information Society Directive. Though Article 9(1) of the OWD states that 'Member States shall bring into force the laws, regulations and administrative provisions necessary to comply with this Directive', this is not addressed within the transposing CPUO Regulations. Even if provisions purporting to modify the Information Society Directive were implemented at national level, they would be insufficient to amend legislation made at EU level. Thus, it appears that the orphan works exception is not wholly compliant with EU law.

In the event that the Information Society Directive is suitably amended, and the orphan works exception is added to its exhaustive list of exceptions and limitations, the exception, as implemented at by the CPUO Regulations, will still have to pass the three-step test to be in full compliance with EU law.

According to the first step of the test, the exception must be confined to a 'certain special case'. ${ }^{84}$ The WTO panel, in applying the test, has clarified that 'certain' is intended to mean 'clearly defined', and that 'special' is intended to mean 'narrow in scope and reach'. ${ }^{85}$ Despite Kerremans' dismissal of this first prong as a mere 'tautology', as 'an exception always entails a special case which differs from the general rule', the fact that courts regularly apply

\footnotetext{
${ }^{83}$ Ioannis Iglezakis, E-Publishing and Digital Libraries: Legal and Organizational Issues (IGI Global 2010) 211.

${ }^{84}$ Berne Convention, Art 9(2).

85 Jane Ginsburg, 'Contracts, Orphan Works, and Copyright Norms: What Role for Berne and TRIPs?' (2009) Columbia Public Law \& Legal Theory Working Papers 1, 16.
} 


\section{It's a Hard Knock Life: A Critique of the Legislative Response to the Orphan Works Problem in the $U K$}

the full test in order to determine the validity of national exceptions indicates that compliance cannot always be assumed. ${ }^{86}$

Academic literature reveals conflicting views as to whether the orphan works exception would constitute a special case. While Schulze opines that a class of works whose authors cannot be located would be too wide to constitute a special case, Bronder takes the opposite stance ${ }^{87}$ However, given that the group of users intended to avail of this particular exception is limited to certain institutions in pursuit of a public-interest, rather than just any individual who cannot locate the owner of the work, it is suggested that the exception is both clearly defined and narrow in scope and reach.

According to the second step of the test, the exception must not conflict with the normal exploitation of the work. ${ }^{88}$ It has been argued that the use of works under the orphan works exception would not pose problems under this step of the test. Because the owners of the orphan works are not extracting economic value from them, it is argued that there is no "normal exploitation'. ${ }^{89}$ This approach is mirrored by the WTO panel's focus on income-generating forms of exploitation..$^{90}$ This interpretation of the second step of the test, it is argued, is unduly blinkered. It presumes that exploitation necessarily equates with financial reward, and fails to account for non-financial forms of exploitation. To 'exploit' is to 'make full use of and derive benefit from a resource'. ${ }^{91}$ Conceivably, an orphan work owner could be considered to be 'making full use' of his work by exercising his choice not to grant licences for its use. He could also be said to be deriving benefit, or at least avoiding potential harm, by choosing not to publicly disclose a work containing information which might tarnish his honour and reputation. In support of this argument, it has been noted that deeming a failure to extract economic value from one's work to be a failure to 'normal[ly] exploit the work' could have the effect of depriving locatable authors of control over exploitations of their work, if they declined to authorise certain uses. ${ }^{92}$

\footnotetext{
${ }^{86}$ Kerremans (n 44) 42; see Case C-462/09 Stichting de Thuiskopie v Opus Supplies Deutschland GmbH and others [2011] ECR I-05331, paras 37-62.

${ }^{87}$ Schulze (n 49) 317; Vigdis Bronder, 'Saving the Right Orphans: The Special Case of Unpublished Orphan Works' (2007) 31 Colum JL \& Arts 409, 418.

${ }^{88}$ Berne Convention, Art 9(2).

${ }^{89}$ Coree Thompson, 'Orphan Works, US Copyright Law and International Treaties: Reconciling Differences to Create a Brighter Future for Orphans Everywhere' (2006) 23(3) Ariz J Int'l \& Comp L 848, 837.

${ }^{90}$ Christophe Geiger, Daniel Gervais and Martin Senftleben, 'The Three-Step-Test Revisited: How to Use the Test's Flexibility in National Copyright Law' (2014) 29(3) Am U Int'l L Rev 581, 594.

91 'Exploit' (Oxford Dictionaries) 〈http://www.oxforddictionaries.com/definition/english/exploit> accessed 27 August 2015.

92 Thompson (n 89) 837.
} 
This reasoning may be squared with the narrow interpretation of 'conflict with the normal exploitation of the work' adopted by the Advocate General in the Infopaq decision. ${ }^{93}$ In this case, it was held that the provision of newspaper extracts containing search terms that had been inputted into a search engine conflicted with the normal exploitation of the work under the three-step test. It was held that making these extracts available was likely to have some impact on full newspaper sales. This impact could not have been expected to be significant, as individuals are unlikely to view short, out-of-context newspaper extracts as acceptable substitutes for full newspapers. Therefore, the implication is that the prospect of even a meagre loss of sales may be sufficient for an exception to fail the second prong of the three-step test. If, applying the reasoning in the previous paragraph, it is possible to "normally exploit' one's works by choosing not to make them available to the public, in the interests of maintaining one's reputation, then it follows that the prospect of even a small amount of damage to that reputation could also result in failure to satisfy the test.

The third step of the test requires that the exception must not unreasonably prejudice the legitimate interests of the author. ${ }^{94}$ In Wilson's view, it is unlikely that any orphan works exception would satisfy this requirement. ${ }^{95}$ She believes that this is because orphan work rightholders are not given an opportunity to express dissatisfaction with the exploitation of their works, often because they are unaware of any exploitation. ${ }^{96}$ Thus, she considers that the interests of the author of an orphan work would be 'unreasonably prejudiced' once his work is used without his permission. ${ }^{97}$ However, this argument fails to account for the fact that rightholders are unlikely to be aware that their works are being exploited when they are used under any exception, whether they are locatable or not. Exceptions, by their nature, allow for deviations from the exclusive rights of exploitation afforded to rightholders under copyright law. Permission is not required to be sought from rightholders in order to make use of their copyrighted works under an exception, nor are rightholders required to be put on notice of such use. ${ }^{98}$ The fact that a rightholder is 'locatable' does not necessarily mean that he is more likely to discover that his work is being used under an exception.

\footnotetext{
${ }^{93}$ Case C-5/08, Infopaq International A/S v Danske Dagblades Forening [2009] ECR I-06569.

94 Berne Convention, Art 9(2).

95 Wilson (n 62) 809.

96 ibid.

97 ibid.

98 Intellectual Property Office, 'Exceptions to Copyright' (GOV.UK, 12 June 2014)

<https://www.gov.uk/exceptions-to-copyright> accessed 27 August 2015.
} 
It is submitted that use of an orphan work under an exception would tend only to unreasonably prejudice the legitimate interests of the author where the work has not previously been published or made available. Failure to make one's work available to the public, whether for profit or not, is likely to be a strong indicator that the author had cause to withhold it. This may have been for a myriad reasons. For example, he may have feared damage to his reputation, or have intended to delay release of the work so that he would have time to publicise it, build media hype, and thus secure greater commercial reward. Alternatively, he may have decided that the work needed to be rewritten or reformulated before it was ready to be publicly released.

For this reason, Bronder suggests that the most cautious approach for introducing an orphan works exception would be to exclude unpublished and undisclosed works from its remit. ${ }^{99}$ The CPUO Regulations have adopted this cautious approach in stating that the exception applies only to works which have been published, broadcast or made publicly accessible. The CPUO Regulations also provide for remuneration in the form of 'fair compensation', which the WTO Panel believes may 'convert an unreasonable prejudice into a reasonable one'. ${ }^{100}$ The orphan works exception seems, therefore, to satisfy this third step of the three-step test.

\section{The Copyright and Rights in Performances (Licensing of Orphan Works) Regulations 2014}

Given that the three-step test is only intended to apply to exceptions and limitations to rightholders' exclusive rights, it would appear, prima facie, that licences should not fall within its remit. Arguably, however, this will not be the case where the effect of the licence is equivalent to that of an exception. Section 16(2) of the Copyright, Designs and Patents Act 1988 states that 'copyright in a work is infringed by a person who, without a licence from the copyright owner, does or authorises another to do any acts restricted by copyright.' This is tempered by section 50, which states that 'where the doing of a particular act is specifically authorised by an Act of Parliament ... then, unless the Act [referring to the CDPA] provides otherwise, the doing of that act does not infringe copyright'. Thus, it is clear that either a licence from the copyright owner, or specific authorisation under an Act of Parliament is required to absolve a user from liability under copyright law.

\footnotetext{
${ }^{99}$ Bronder (n 87) 430.

${ }^{100}$ Paul Torremans and others, 'Orphan Works - Compatibility of the Draft Directive with the International Norms' <http://kluwercopyrightblog.com/files/2012/06/Orphan_works_opinion_final.pdf> accessed 27 August 2015,3 .
} 
Section 6(2)(b) of the LOW Regulations provides for the grant of licences which permit acts in respect of orphan works that are 'restricted by the copyright or sections 182, 182A, 182B, 182C, 182CA, 183 or 184 of the Act [referring to the CDPA]'. Evidently, a licence from a licensing body is not the same as a licence from the copyright owner, as required by the CDPA. Furthermore, Rosati notes that it is the LOW Regulations, devised by the Secretary of State, which specifically provide for the grant of licences to use orphan works, rather than the relevant Act of Parliament (meaning the ERRA). ${ }^{101}$

Thus, for the licensing system provided for by the LOW Regulations to have the intended effect, whilst also complying with the CDPA, it must operate in practice as an exception. As an exception, it will need to be added to the exhaustive list of limitations and exceptions in the Information Society Directive to be permissible under EU copyright law. It must also comply with the three-step test set out in the Berne Convention.

It is submitted that the 'exception' provided by the LOW Regulations would be much less likely to satisfy the first step of the test than the orphan works exception enumerated by the CPUO Regulations. It is much less clearly defined and restricted in scope. Unlike the orphan works exception, which is limited to certain institutions pursuing a public interest mission, any applicant complying with the diligent search requirements under the LOW Regulations may be granted a territorial, non-exclusive licence. Additionally, while the uses permitted by the orphan works exception are limited to making the work available to the public and reproduction for the purposes of digitisation, making available, indexing, cataloguing, preservation or restoration, licences granted under the LOW Regulations permit any acts restricted by copyright.

In light of the previous analysis of the meaning of the 'normal exploitation of the work', and the conclusion that it encompasses non-financial forms of exploitation, including purposely withholding one's work from the public sphere, it appears that the licensing system under the LOW Regulations would also fail the second step of the test. If the rightholder in an orphan work prefers to 'exploit' said work by keeping it undisclosed, then a licence permitting 'any acts restricted by the copyright' must necessarily interfere with the rightholder's desired form of exploitation.

Turning to the third step of the test, the fact that orphan works subject to the licensing scheme under the LOW Regulations are not limited to those which are published or have been made available is likely to result in unreasonable prejudice to the legitimate interests of the

${ }^{101}$ Rosati (n 60) 21. 


\section{It's a Hard Knock Life: A Critique of the Legislative Response to the Orphan Works Problem in the $U K$}

rightholder. In failing to exclude works that have not been published or made available, the LOW Regulations disregard the cautious approach recommended by Bronder and adopted by the OWD and CPUO Regulations. ${ }^{102}$ This may result in particularly undesirable consequences for rightholders. In light of the afore-discussed reasons why a rightholder might consciously delay or decline to disclose his work, such consequences could amount to reputational damage, or reduction in revenues in the event of future financial exploitation of the work.

\section{The Copyright and Rights in Performances (Extended Collective Licensing) Regulations 2014}

Given that extended collective licences, like licences granted under the LOW Regulations, operate as de facto exceptions, it is submitted that they, too, are subject to the requirements of the three-step test. Despite the fact that the Satellite and Cable Directive has endorsed the applicability of the extended collective licensing model in certain circumstances, and that the Information Society Directive is without prejudice to agreements in Member States concerning the management of rights such as extended collective licensing, this should not be taken to guarantee that its application will always be fully compliant with international legal requirements. ${ }^{103}$

Though there is no explicit restriction on the types of copyright-protected work and uses in respect of which extended collective licences may be granted, such licences will only be available in respect of works and uses represented by an authorised 'relevant licensing body'. ${ }^{104}$ Individual licensing bodies will only be authorised to issue extended collective licences for specific uses of specific kinds of work. As Riis and Schovsbo observe, an assessment of whether extended collective licensing schemes constitute 'certain special cases' should, therefore, consider individual schemes rather than the aggregate number permitted under a particular set of regulations. ${ }^{105}$ Conducting an assessment of licensing schemes in the aggregate could lead to anomalous results, particularly under the first step of the test. There would necessarily come a point where the authorisation of another scheme would cast the 'exception' beyond the bounds of a certain special case. This would not allow for consideration of the nature of the uses and works covered by the scheme at the tipping point, which may have been extremely limited in scope. Given that the regulations have only recently been introduced,

\footnotetext{
102 Bronder (n 87) 430.

${ }^{103}$ Council Directive 93/83/EEC on the coordination of certain rules concerning copyright and rights related to copyright applicable to satellite broadcasting and cable retransmission [1993] OJ L 248/15.

${ }^{104}$ ECL Regulations, s 4(1).

105 Thomas Riis and Jens Schovsbo, 'Extended Collective Licenses and the Nordic Experience: It's a Hybrid but Is It a Volvo or a Lemon?’ (2010) 33 Colum J L \& Arts 471, 487.
} 
the scope of the respective extended collective licensing schemes authorised thereunder remains to be seen.

Just as under the LOW Regulations, however, the category of potential beneficiaries entitled to apply for extended collective licences is unlimited. In addition, because the ECL Regulations are not specifically intended to tackle the orphan works problem, they do not require applicants for licences to undertake any form of diligent search as a prerequisite to being granted a licence. It is unlikely, therefore, that extended collective licences granted under the regulations would be deemed sufficiently clearly defined and narrow in scope and reach to satisfy the first prong of the test, regardless of how limited the class of works and permitted uses.

This said, a number of academics have argued that the extended collective licensing systems for copyright which are commonplace in Nordic countries would satisfy the second step of the test. ${ }^{106}$ Far from conflicting with the normal exploitation of copyright works, they suggest that, in these countries, having a large portion of copyrights and related rights administered by way of extended collective licence is itself a form of normal exploitation. Even if this were the case, however, it is far from clear that extended collective licensing could be considered a form of 'normal exploitation' of copyright works in the UK. Such systems have been in place in Nordic countries since the 1960s, whereas they have only recently been introduced in the UK. ${ }^{107}$ In the event that this form of licensing does become accepted and popular in the UK, it is unclear at exactly what point it shifts from being an abnormal form of exploitation to a normal form. Given that collective rights management is 'still rather underdeveloped ... in the photographic and audiovisual fields', however, it must be assumed that this shifting process will be slow. ${ }^{108}$

Indeed, this raises an interesting question over the correct interpretation of the second step of the test where two forms of 'normal exploitation' conflict. Assuming that there are many ways in which a work may be exploited, and that both exploitation under an extended collective licence and non-financial exploitation through conscious non-disclosure of one's work constitute forms of normal exploitation, it is clear that the two are not fully compatible.

\footnotetext{
106 ibid.

${ }^{107}$ Henry Olsson, 'The Extended Collective Licence as Applied in the Nordic Countries' (Kopinor, 20 May 2005) <http://www.kopinor.no/en/copyright/extended-collective-license/documents/the-extended-collective-licenseas-applied-in-the-nordic-countries $>$ accessed 27 August 2015.

108 Stef van Gompel, 'Audiovisual Archives and the Inability to Clear Rights in Orphan Works' (2007) 4 IRIS plus 1,5 .
} 


\section{It's a Hard Knock Life: A Critique of the Legislative Response to the Orphan Works Problem in the $U K$}

Although a full exploration of this issue is beyond the scope of this paper, it is conceivable that each might render the other non-compliant with the second step of the test.

Moving on to consider the third step of the test, the ECL Regulations - like the LOW Regulations - contain no broad provision excluding works which have not been published or made available from the scope of extended collective licensing schemes. However, it may be that the categories of use and work in respect of which individual relevant licensing bodies seek authorisation to operate extended collective licensing schemes are, in fact, limited in this way. Therefore, whether individual schemes unreasonably prejudice the legitimate interests of the rightholder will vary from case to case.

If unpublished and undisclosed works are not excluded, it is unlikely that remuneration provisions in the ECL Regulations will suffice to 'convert an unreasonable prejudice into a reasonable one'. ${ }^{109}$ This is because extended collective licensing schemes tend to work in favour of local authors. ${ }^{110}$ Foreign rightholders 'often do not get the remuneration they deserve for use of their works'. ${ }^{111}$ Though section 4(4)(e) obliges relevant licensing bodies to have arrangements in place for contacting non-member right holders and distributing net licence fees, no guidance is provided as to what such arrangements should entail. The regulations state only that the arrangements should be 'appropriate for the proposed scheme, having regard to the interests of non-member rightholders' ${ }^{112}$ The fact that administration fees deducted by the licensing body must be 'reasonable' suggests that high notification and distribution costs for rightholders in foreign jurisdictions may not be covered, and it is therefore less likely that they will receive the remuneration to which they are entitled. ${ }^{113}$

Aside from the questionable compatibility of the ECL Regulations with the requirements under the three-step test, having to 'opt-out' to avoid having one's work exploited under an extended collective licence could constitute a forbidden formality under Article 5(2) of the Berne Convention. ${ }^{114}$ While Ringnalda suggests that the Convention may only have intended to prohibit formalities forming a barrier to the initial grant of copyright, this interpretation does not correspond with the wording of the instrument. ${ }^{115}$ Article 5(2) clearly states that 'the enjoyment and the exercise of these rights shall not be subject to any formality.'

\footnotetext{
109 Torremans and others (n 100).

${ }^{110}$ Alain Strowel, 'The European 'Extended Collective Licensing' Model' (2011) 34 Colum J L \& Arts 665, 669.

111 ibid.

112 ECL Regulations, s 4(4)(e).

113 ibid, s 18(1).

${ }^{114}$ ECL Regulations, s 16(1).

115 Ringnalda (n 61) 10.
} 
This indicates that the prohibition on formalities extends beyond the grant of rights, to the use and enjoyment of those rights that have been granted. Given that copyright protection vests automatically in original works which are recorded in material form, it certainly appears that having to fill out and issue an 'opt-out notice' in order to prevent one's work from being licensed out against one's will would affect the enjoyment and exercise of exclusive rights under copyright law. ${ }^{116}$

Finally, it must be noted that the provisions of both the ECL and LOW Regulations also risk undermining the principle of subsidiarity. ${ }^{117}$ As, under Article 4 of the Treaty on the Functioning of the European Union, the European Commission and European Member States share competence with respect to intellectual property law, both are authorised to adopt binding legislative acts in this field. ${ }^{118}$ According to Article 2, however, this is subject to the caveat that Member States may only exercise their legislative competence insofar as the EU has 'not exercised, or has decided not to exercise, its own competence'.

Because the EU has legislated in the OWD for an exception to copyright for certain uses of orphan works by certain beneficiary organisations, Member States are forbidden under Article 4 from usurping this exercise of legislative competence. They cannot legislate in a manner that undermines the exception. However, in enacting the ERRA, and the LOW and ECL Regulations thereunder, the UK appears to have done just that. Despite the fact that a licence fee must be paid in order to obtain a licence under the LOW Regulations, which is not required upfront to avail of the orphan works exception, licences granted under the LOW Regulations are likely to be much more attractive to prospective users of orphan works. ${ }^{119}$ Users can be certain that they will not incur liability for copyright infringement by using an orphan work when operating under a licence, whereas they cannot be so certain that their actions fall within the scope of the orphan works exception. Licences granted under the ECL Regulations offer an even more attractive solution for prospective users of orphan works, as they do not require any form of diligent search.

Evidently, licences under both the LOW and ECL Regulations may be granted to the same institutions intended to benefit from the orphan works exception, and in respect of the same type of works and uses covered by the exception, whilst offering a greater degree of legal

\footnotetext{
116 ECL Regulations, s 16(1).

117 Céline Chateau, 'The Principle of Subsidiarity' (Fact Sheets on the European Union - 2015, June 2015) <http://www.europarl.europa.eu/ftu/pdf/en/FTU 1.2.2.pdf> accessed 27 August 2015.

118 Pierre Véron, Concise International and European Intellectual Property Law: TRIPS, Paris Convention, European Enforcement and Transfer of Technology (Kluwer Law International 2011) 11.

${ }^{119}$ Rosati (n 8) 13.
} 
certainty. Therefore, it appears that the regulations impermissibly supersede the provisions of the OWD, as transposed in the UK by the CPUO Regulations. ${ }^{120}$

\section{G. PROTECTION OF MORAL RIGHTS}

The potential for infringement of moral rights also arises where orphan works are used under any of the models discussed. However, the dearth of academic literature on this topic suggests that moral rights protection has been overshadowed by the goal of 'free[ing] orphan works'. ${ }^{121}$ The ECL Regulations do not refer to moral rights at all, and, though the LOW and CPUO Regulations purport to offer some protection of the moral rights of authors, this protection appears to be more tokenistic than substantive.

While the failure to properly address moral rights protection in the UK regulations is unsurprising, given the traditional British 'scepticism towards claims that authors deserve special protection in law', the UK remains obliged, under EU law, to protect such rights. ${ }^{122}$ Authors' rights of attribution (encompassing the right to object to false attribution) and integrity are explicitly recognised by Article 6bis of the Berne Convention, and provision for safeguarding those rights must be made at national level. These rights may be waived, but are typically non-assignable. ${ }^{123}$

\section{The Copyright and Rights in Performances (Certain Permitted Uses of Orphan Works) Regulations 2014}

The CPUO Regulations state that for an orphan work to be used under the exception, it must be 'reasonable to assume that the rightholders would not oppose the use of the work'. ${ }^{124}$ This appears to hint at the right of integrity. Upon closer inspection, however, it becomes clear that the individual 'protected' is the rightholder, rather than the author. Moral rights are intended to protect the author of a work, and it is not guaranteed that the author and rightholder will be one and the same. Indeed, a determination of how reasonable it is to assume that a rightholder or author would not oppose use of the work necessarily requires some degree of information about that individual and how he intends the work to be perceived.

\footnotetext{
120 ibid.

${ }^{121}$ Lydia Pallas Loren, 'Abandoning the Orphans: An Open Access Approach to Hostage Works' (2012) 27 Berkeley Tech LJ 1431, 1452-1453.

${ }^{122}$ William Cornish, David Llewelyn and Tanya Aplin, Intellectual Property: Patents, Copyright, Trade Marks and Allied Rights (7th edn, Sweet \& Maxwell 2010) 514.

${ }^{123}$ Agnes Lucas-Schloetter, 'Is There a Concept of European Copyright Law?' in Irini Stamadouti and Paul Torremans (eds) EU Copyright Law: A Commentary (Edward Elgar 2014) 14.

${ }^{124}$ CPUO Regulations, s 2(4).
} 
The regulations also hint at the right of attribution by requiring that, in the course of the permitted use, the relevant body 'acknowledge the name of any author or other rightholder in the work who has been identified'. ${ }^{125}$ Because no allowance is made for protecting the author's right of integrity, however, it may be the case that including the author's name on a particularly derogatory use of the material could cause more harm than good to his reputation.

\section{The Copyright and Rights in Performances (Licensing of Orphan Works) Regulations 2014}

The LOW Regulations, also hinting at protection of the right of integrity, state that the relevant licensing body may refuse to grant an extended collective licence 'on the ground that, in its reasonable opinion, a proposed use or adaptation is not appropriate...[or] constitutes derogatory treatment of the work'. ${ }^{126}$ However, the fact that the licensing body may refuse to grant a licence on such grounds indicates that it is not obliged to. Because licensing bodies justify their existence by granting licences, they do not have an interest in being unduly deferential to the interests of authors by rejecting 'derogatory' uses. It is, therefore, unlikely that the moral right of integrity would be adequately protected.

In any case, it is not clear why a licensing body should be in a position to determine whether or not a use or adaptation is inappropriate or derogatory. Despite the fact that UK courts have tended to favour an objective rather than subjective approach to the determination of whether use of a work is derogatory, and therefore prejudicial to the honour and reputation of the author, it is, appropriately, a judicial determination. ${ }^{127}$ The LOW Regulations also state that orphan licences granted by the authorising body must 'provide that the use of an orphan work does not affect the moral rights of an author'. ${ }^{128}$ This provision has the effect of absolving users from liability for the infringement of moral rights. Thus, licensees are afforded free rein to use orphan works without considering whether their use would be likely to affect the moral rights of the author.

\section{The Copyright and Rights in Performances (Extended Collective Licensing) Regulations 2014}

The ECL regulations contain no explicit recognition that the licensing of rights in works on behalf of others might give rise to infringement of moral rights, and contain no safeguards to prevent this occurring.

\footnotetext{
125 ibid, s 6(d).

${ }^{126}$ LOW Regulations, s 6(5)(a).

${ }^{127}$ Lionel Bently and Brad Sherman, Intellectual Property Law (4th edn, Oxford University Press 2014) 286-287.

${ }^{128}$ LOW Regulations, s 6(2)(e).
} 
The failure of the UK's three-pronged orphan works solution to consider moral rights is particularly concerning for two reasons. First, the development of technology has opened up a myriad of ways in which moral rights may be infringed. Poor quality digital display, watermarking, copying and pasting alongside other materials, and embedding links in digitised copies of works may all affect the moral right of integrity. ${ }^{129}$ In addition, digital works are easily stripped of metadata which could attribute them to a particular author. ${ }^{130}$

Secondly, the fact that the UK regulations provide only for pecuniary, and not injunctive, relief for reappearing rightholders means that such rightholders may be unable to put a stop to uses they know are likely to infringe the author's right of integrity. The CPUO Regulations merely provide that reappearing rightholders must be provided with fair compensation for use of the work. ${ }^{131}$ The LOW Regulations, in addition to providing for payment of a licence fee, state that orphan licences 'shall continue for the remainder of their unexpired term, or until the expiration of the notice period ... notwithstanding the fact that the rightholder is identified'. ${ }^{132}$ The legality of this provision is particularly questionable in light of the fact that the reappearance of rightholders necessarily puts an end to the orphan status of the work. Because the regulations only permit the issuance of licences in respect of orphan works, the legal basis for such licences falls away when works are no longer orphans. A similar question arises in respect of the ECL Regulations. Section 16(4)(b) states that, even if a nonmember rightholder attempts to opt-out of the system, licences already granted in respect of that rightholder's work(s) will remain valid until their termination dates. However, the fact that opting out enables rightholders to 'exclude or limit the grant of licences under an extended collective licensing scheme in relation to their rights in a relevant work' would appear also to remove the legal basis for the continued validity of extended collective licences issued in respect of those works. ${ }^{133}$

\footnotetext{
${ }^{129}$ Guy Pessach, 'The Author's Moral Right of Integrity in Cyberspace-A Preliminary Normative Framework' (2010) 41(2) IIC 187, 244-245.

${ }^{130}$ Colin Davies and Tania Cheng, 'Public Benefit or Private Loss - Orphan Works and the Enterprise and Regulatory Reform Act 2013' (2013) 18(3) Journal of Computer, Media and Telecommunications Law 74, 78.

${ }^{131}$ CPUO Regulations, s 7(3).

${ }^{132}$ LOW Regulations, s 12(3).

${ }^{133}$ ECL Regulations, s 16(1).
} 


\section{H. CONCLUSION}

It is clear from the foregoing analysis that the three-pronged solution to the orphan works problem which has been implemented in the UK does not fully align with the objectives sought to be achieved.

First, it does not generate sufficient legal certainty for prospective users of orphan works. The CPUO Regulations contain a number of poorly defined terms, impose obligations upon users which they cannot confirm have been suitably fulfilled and provide no guidance regarding the appropriate course of action for users where foreseeable difficulties arise. The LOW Regulations also contain a number of poorly defined terms and, by affording broad discretion to the relevant licensing body to refuse to grant extended collective licences on 'reasonable grounds', leave users uncertain as to whether they are likely to be granted a licence following a diligent search. Though the ECL regulations appear to offer more legal certainty to prospective users, this has been undermined by a statement by the Intellectual Property Office to the effect that it is not intended for the licensing of orphan works.

Secondly, the solution is limited in its ability to facilitate cross-border access to orphan works and their use in the context of mass digitisation. The orphan works exception implemented by the CPUO Regulations is extremely narrow in scope, and represents just one of a number of ways that the OWD exception may be interpreted by European Member States. The harmonising effect of the principle of mutual recognition must not be overstated, considering existing differences between national copyright laws. Indeed, those seeking to use orphan works for the purposes of mass digitisation are likely to be unable to avail of the exception, considering the prohibitive cost of carrying out a diligent search in respect of each work, and the fact that commercial uses are excluded from its scope. Even non-commercial mass digitisation initiatives will be hindered by the fact that stand-alone photographs are not covered by the exception. Though the licensing systems implemented by both the LOW and ECL Regulations are less restricted in scope, the fact that licences issued under both systems are valid only within the UK negates any possibility of disseminating orphan works online. The LOW Regulations also require a diligent search in respect of each work, which, as noted, would be prohibitively expensive on a mass scale.

Thirdly, each prong of the solution appears to conflict, in some way, with international legal obligations. No aspect of the solution complies fully with each step of the three-step test. The system for opting-out of extended collective licensing schemes under the ECL Regulations 
also appears to constitute a forbidden formality under the Berne Convention. Furthermore, both the LOW and ECL Regulations risk undermining the principle of subsidiarity.

Fourthly, moral rights do not appear to be sufficiently protected by the solution. The half-hearted 'protections' for moral rights included in the CPUO and LOW Regulations appear more tokenistic than substantive, and the ECL Regulations provide no safeguards at all in this regard.

The UK's legislative response to the orphan works problem combines the weaknesses of three different approaches. Although each of these approaches also has attendant strengths, this paper argues that the system, as a whole, fails to fully realise a number of stated objectives. It is hoped that the paper has served to identify aspects of this system which require amendment or revision to more properly meet these objectives. In executing such amendments and revisions, however, the need to maintain a balance 'between the rights of the authors, on the one hand, and the interest of the public in access to protected works, on the other' must not be overlooked. ${ }^{134}$

${ }^{134}$ Gillian Davies, Copyright and the Public Interest (Sweet \& Maxwell 2002) 7. 